\title{
Feasibility of Replacement Postponement Based on Insulation Test for Aged Gas-Insulated Power Equipment
}

\author{
Hisashi Goshima Member (CRIEPI, goshima@criepi.denken.or.jp) \\ Masafumi Yashima Member (CRIEPI, yashima@criepi.denken.or.jp) \\ Takatoshi Shindo Member (CRIEPI, shindo@criepi.denken.or.jp) \\ Tadasu Takuma Member (Tokyo Denki University/CRIEPI, takuma@criepi.denken.or.jp)
}

Keywords: insulation test, Weibull distribution, replacement postponement, V-t characteristics, gas-insulated power equipment

With the urgent need for cost reduction in electric power equipment, investment in equipment will be controlled and the number of aged equipment will increase in the future. Moreover, it is requested that aged equipment should be used to the utmost limit by postponing the replacement to as late a date as possible. At this time, it is important to discuss how we can evaluate and guarantee the residual lifetime of equipment. As a method of replacement postponement, there is an alternative possibility of guaranteeing the lifetime by executing an insulation test on the aged equipment again.

In this paper, we investigate long-time V-t characteristics and the meaning of $\mathrm{AC}$ insulation tests for gas-insulated power equipment such as gas insulated switchgear (GIS). Furthermore, we discuss the feasibility to replacement postponement by executing the insulation test on the aged equipment again.

Figure 1 shows the deterioration tendency and maintenance concept for typical power equipments. The " $n$ " value of long-time V$\mathrm{t}$ characteristics for a GIS spacer is reported to be from 10 to 16 in V-t characteristics of the spacer model without a void. Therefore, the principal deterioration factor is regarded as insulation deterioration because the " $n$ " value is small. However, electric field stress is generally controlled in order to ensure long-term insulation

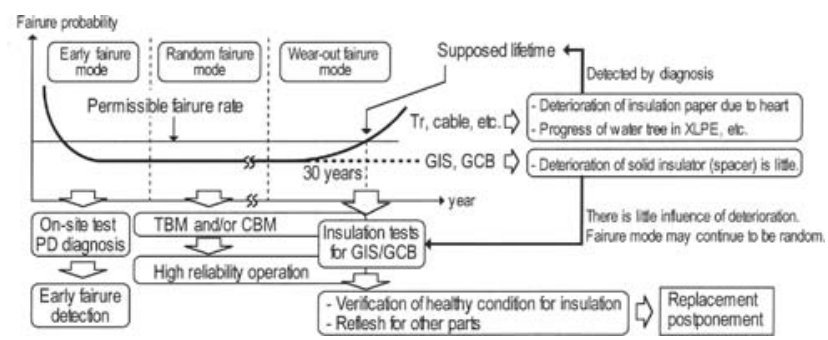

Fig. 1. Deterioration tendency and maintenance concept for typical power equipments performance. In GIS, the electric field strength in a solid insulator such as the spacer after 30 years is 2 times larger than the electric field constantly applied to the solid insulator of GIS. Therefore, it is supposed that the random fairure mode continue and the "bath-tub curve" (fairure probability) is still flat (constant) after 30 years. In this case, it is difficult to detect insulation deterioration by some diagnosis such as partial discharge measurement as transformer and cable. On the contrary, it may be possible to prove a healthy condition by executing the insulation test on the aged equipment again after refreshment of equipment components such as gas exchange, contacts of switching devices, sealing materials, and so on. Thus, postponement of replacement may be applicable for the aged GIS. Figure 2 shows flowchart of replacement postponement for aged GIS.

From the viewpoint of replacement postponement, it is necessary to confirm the healthy condition of the inside (initially with no void) of a solid insulator, such as the spacer in GIS, if the equipment is intended for long-term use (more than 30 years). The " $n$ " value of V-N characteristics of a solid insulator is comparatively small. Therefore, it is considered that microvoids at the interface of the electrode in the spacer are generated due to the application of repeated surge; partial discharge occurs, and deterioration progresses. From this mechanism, it is necessary to discuss whether microvoids due to repeated overvoltage are generated and if partial discharge occurs under working voltage. Therefore, it is important to prove the healthy condition of the solid insulator when two different levels (waveform or value) of voltage are applied to the solid insulator. Hence, it is necessary to acquire fundamental data on long-time V-t characteristics and statistical parameters such as "n" value that consider deterioration due to repeated overvoltage. If these fundamental data are accumulated, an insulation test method for replacement postponement of gas-insulated equipment can be proposed.

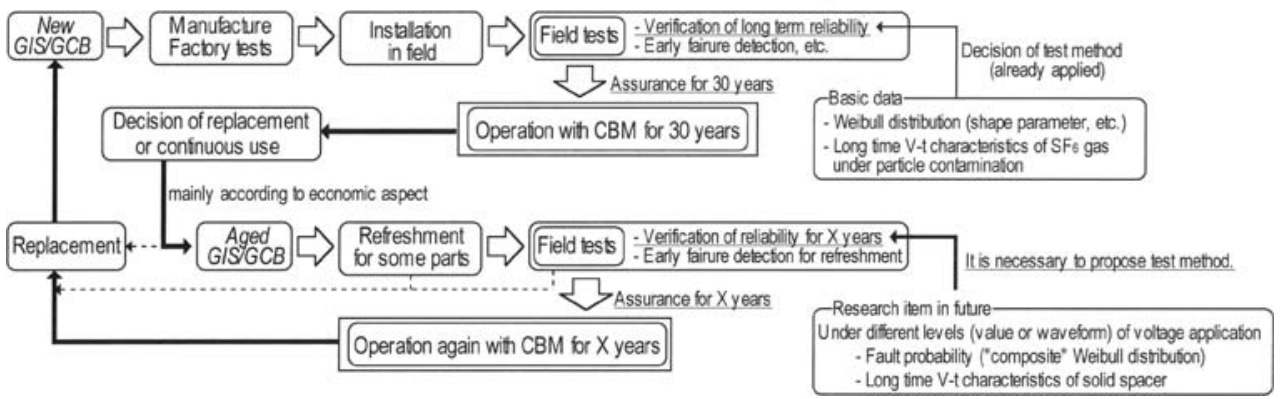

Fig. 2. Flowchart of replacement postponement for aged GIS 


\title{
経年ガス絶縁機器の絶縁試験によるリプレース時期延伸の可能性
}

\author{
正 員 五島 久司* 正 員 八島 政史* \\ 正員 新藤 孝敏* 正員 宅間 董*,**
}

\section{Feasibility of Replacement Postponement Based on Insulation Test for Aged Gas-Insulated Power Equipment}

Hisashi Goshima*, Member, Masafumi Yashima*, Member, Takatoshi Shindo*, Member, Tadasu Takuma***, Member

With the urgent need for cost reduction in electric power equipment, investment in equipment will be controlled and the number of aged equipment will increase in the future. Moreover, it is requested that aged equipment should be used to the utmost limit by postponing the replacement to as late a date as possible. At this time, it is important to discuss how we can evaluate and guarantee the residual lifetime of equipment. As a method of replacement postponement, there is an alternative possibility of guaranteeing the lifetime by executing an insulation test on the aged equipment again.

The present standards of AC insulation tests for high voltage power equipment in Japan are based on the reliability evaluation according to the Weibull distribution assumed as fault occurrence probability of the equipment. The present evaluation is not considered a proper one as it doesn't take into account non-accidental change of the equipment with time. One of the authors has pointed out this problem in a recent paper.

In this paper, we investigated long-time V-t characteristics and the meaning of AC insulation tests for gas-insulated power equipment. Furthermore, we discuss the fault probability when two different levels (waveform or value) of voltage are applied to equipment. Finally, we investigate the feasibility to replacement postponement by executing the insulation test on the aged equipment again.

キーワード：絶縁試験，ワイブル分布，リプレース時期の延伸， V-t 特性，ガス絶縁電力機器

Keywords: insulation test, Weibull distribution, replacement postponement, V-t characteristics, gas-insulated power equipment

\section{1. まえがき}

電力輸送設備の維持・管理に対するコスト削減の要請か ら，各種診断技術を活用した保守・保全コストの削減，既 設設備の極限までの有効活用，リプレース（交換）時の健 全部品の再利用（リユース）などが重要な課題となってい る。特にこれまでは, 需要増に対応した機器にリプレース が進められ，高経年機器はあまり存在しなかったが，今後 は設備投資が抑制され，高経年機器が着実に増加するとと もに，リプレース時期を極力延伸させて既設設備を極限ま

\footnotetext{
* (財) 電力中央研究所電力技術研究所

干 240-0196 横須賀市長坂 2-6-1

Central Research Institute of Electric Power Industry

2-6-1, Nagasaka, Yokosuka 240-0196

** 東京電機大学工学部

于101-8457 東京都千代田区神田錦町 2-2

Tokyo Denki University

2-2, Kanda-nishikimachi, Chiyoda-ku, Tokyo 101-8457
}

で使い切ることが求められる。このとき, 機器の健全性や 余寿命をどのように評価し, また保証するかが大きな課題 となる。また，極限まで使用した機器は, リプレースの際 は極力健全部品をリユースすることも新設機器のコスト低 減の上で有効である。さらに，アジア地域における中古品 のマーケットの可能性からも, 健全品のリユースは重要で ある。

このような観点から, 筆者らは, リプレース時期の延伸手 法の一つとして, 経年機器の絶縁試験による健全性評価の 可能性について検討した。機器据え付け後の現地試験での 過電圧の印加は, 初期絶縁性能が経年とともに逆 $\mathrm{n}$ 乗則に 従って減衰したとしても, 期待寿命経過後（例えば経年 30 年）に所要の絶縁性能が維持されていることを検証するも のと解釈されている。機器の絶縁性能が実際にこのような 減衰特性を示すかどうかは議論が必要と考えられるが，一 つの考え方として, 経年機器に再度, 過電圧を印加した絶 縁試験を実施することにより，リプレース時期の延伸が保 
証される可能性がある。このようなリプレース時期の延伸 方法は，有効な CBM (Condition Based Maintenance; 状 態監視保全）によって機器の状態が良好に保持されている こと，ユーザの自己責任を前提とする割り切りが必要とな るが，過電圧印加と絶縁性能に関する長期 V-t 特性の関係 に理論的説明が与えられれば，実用の可能性はあると考え られる。

一方, 機器の故障確率は, 構成要素の絶縁媒体や機器そ のものの V-t 特性を基にしてワイブル分布で与えることが 行われる。ところが，過電圧と常規電圧など異なる電圧が 印加されたとき，故障確率をどのように与えるかはいまだ に明らかになっていない。この点から，近年，ワイブル分 布に基づく機器の信頼度計算掞よび機器の絶縁試験法（試 験電圧の選定)に関する問題点が提起されている(1)。

以上の経緯から，本論文では，ガス絶縁開閉装置（GIS） を中心としたガス絶縁機器を対象に, 現行の長時間 V-t 特 性打よび絶縁試験の考え方を調査するとともに，3種類の モデルを設定して，印加時間や值の異なる電圧が印加され た場合の故障確率の考え方を整理した。さらに，経年機器 における再度の絶縁試験によるリプレース時期延伸の可能 性について検討した。

\section{GIS の長時間 V-t 特性と交流絶縁試験}

〈2・1〉 長時間 V-t 特性 GIS の主たる絶縁構成は, $\mathrm{SF}_{6}$ ガスと固体絶縁物の並列構成であり, 試験電圧はそれぞれ の絶縁特性を調査し，最弱の特性で検討されている。GIS に係わる絶縁媒体の長時間 V-t 特性に関する報告例をまと めたものを表 1 に示す。GIS 内部のような準平等電界での 高気圧 $\mathrm{SF}_{6}$ については，部分放電開始後，即絶縁破壊に至 りやすく部分放電開始と絶縁破壊はほほ等しいと考えられ る。また，絶縁破壊は，電極表面の突起や微小な異物など による高電界部分の弱点により生じると考えられ，絶縁破 壊電圧の分布，破壊時間の分布はワイブル分布によく合っ ている。 $\mathrm{SF}_{6}$ ガス自体は化学的に安定であり, 通常の使用 状態では経年劣化は生じないと考えられている。このため, $\mathrm{SF}_{6}$ ガスで V-t 特性が現れるのは, 時間の経過とともに弱
点から放電の発生する確率が増すためであると考えられる。 このことから，準平等電界（清浄時）の長時間 V-t 特性の $\mathrm{n}$ 值は大きく, $74^{(2)} \sim 82^{(3)}$ と報告されている。一方, 金属 異物混入時では，短時間と長時間で $\mathrm{n}$ 值が異なるデー夕 (3) や，異物長によって $\mathrm{n}$ 值が異なるデー夕(2) などが報告され ているが，全般的には 30 以上となっている。

スペーサなど固体絶縁物中においては, 最も電界強度の大 きい部分は金属 (埋込電極) と絶縁物の界面に存在する。ボ イド久陥がない場合， $\mathrm{n}=10 \sim 16$ 程度と評価されている ${ }^{(4)}$ 。 また，絶縁破壞直前の部分放電は検出されていない。一方， ボイドありおよびなしのエポキシ注形絶縁物における絶縁 破壞に対する長時間 V-t 特性においては，ボイドなしでは $\mathrm{n}=16$ ，ボイドあり試料では $\mathrm{n}=7.3$ 等の報告例があり ${ }^{(5)}$ ，ボ イドにより $\mathrm{n}$ 值は小さくなる。

$\langle\mathbf{2} \cdot \mathbf{2}\rangle \quad$ 交流試験電圧の選定 ${ }^{(2)} \quad$ 試験電圧と印加時間 は, 長時間 V-t 特性を基に決定されている。絶縁破壊の前 駆現象である部分放電試験で異常を検出することが望まし いが，ガス絶縁機器では通常，部分放電発生後直ちに破壊 に至るため，絶縁破壊に対する V-t 特性を用いている。

GIS の絶縁構成要素としては，ガスそのもののように劣 化はなく, ある確率のもとでしか破壞が生じないと考えら れるものと, 固体絶縁物のように, 高電界においては劣化 が進行するが，使用期間では十分所期性能を保持できると 解釈できる寿命検証とがある。試験電圧決定で考慮すべき 絶縁特性としては, 固体絶縁物は例えば 30 年というょう な長期の常規対地電圧に耐えることが要求される。ここで 無ボイド固体絶縁物の V-t 特性から, 劣化が $\mathrm{n}=10 \sim 16$ の 逆 $\mathrm{n}$ 乗則に従うとすれば, 30 年後の絶縁物か耐え得る電界 強度は, 通常, GIS の絶縁物に常時加わる電界強度の 2 倍 以上の大きさを持っていることになる。このため，固体絶 縁物の劣化は考慮に入れなくてもよいと考えられ, 考慮す べきはガス中の絶縁特性とされている。GIS はガス中に目 視できるような異物（品質管理值として $3 \sim 5 \mathrm{~mm}$ 以上）は 残留しないように製造されているが，現行の交流試験電圧 選定のベースとなった $\mathrm{V}-\mathrm{t}$ 特性デー夕は, 安全面から異物 存在時のデータが用いられている。

表 1 GIS の長時間 V-t 特性に関するデー夕

Table 1. Summary of data on long term V-t characteristics of GIS.

\begin{tabular}{|c|c|c|c|c|}
\hline Insulation medium & \multicolumn{2}{|r|}{$\mathrm{SF}_{6}$ gas } & \multicolumn{2}{|c|}{ Epoxy resin (spacer) } \\
\hline Condition & Clean & with metallic particle(including spacer surface) & Inside without void & Inside with void \\
\hline Typical " $n$ " values of V-t characteristics & $\begin{array}{l}82^{(3)} \\
74^{(2)}\end{array}$ & $\begin{array}{l}69{\text { (long time) })^{(3)}} \\
30(\text { short time: up to } 10 \mathrm{~min})^{(3)} \\
62-38(\text { particle length } 10-30 \mathrm{~mm})^{(2)}\end{array}$ & $\begin{array}{l}10-16^{(4)}, 16^{(5)} \\
20.1(1 \mathrm{~min}-1 \mathrm{~h}), 15(\text { more than } \\
1000 \mathrm{~h}), 8.3(1-1000 \mathrm{~h})^{(6)}\end{array}$ & $\begin{array}{l}7.3^{(5)} \\
4-8^{(4)}\end{array}$ \\
\hline Typical "a" values of V-t characteristics & $\begin{array}{l}0.35-0.5^{(3)} \\
0.25-0.5^{(2)}\end{array}$ & $\begin{array}{l}1 \text { (short time), } \quad 0.5 \text { (long time) }^{(3)} \\
0.6-1.3^{(2)}\end{array}$ & $\begin{array}{l}0.8-0.9(7) \\
0.6-1.4(7)\end{array}$ & \\
\hline Typical " $m$ " values of $\mathrm{V}$ - $\mathrm{t}$ characteristics & $20-25(2)$ & $30-35^{(3)}$ & & \\
\hline $\begin{array}{l}\begin{array}{l}\text { Typical " } n \text { " values of } \\
\text { characteristics }\end{array} \\
\text { ch-N }\end{array}$ & & $\begin{array}{ll}\text { Spacer surface } & \mathrm{Ll}^{* 1}: 124^{(9)} \\
& \mathrm{Sl}^{* 1}: 134^{(9)} \\
\end{array}$ & $\begin{array}{l}\mathrm{Ll}^{* 1}: 35.7^{(8)} \\
\mathrm{Sl}^{* 1}: 45.5^{(8)}\end{array}$ & \\
\hline
\end{tabular}

*1: LI: Lightning impulse, SI: Switching impulse 
〈2·3〉リプレース延伸に向けた健全性評価上述の とおり GIS の場合，主絶縁媒体の $\mathrm{SF}_{6}$ は基本的に劣化が 無く, 固体絶縁物も電界ストレスが小さいため, 30 年程度 での使用では劣化事象は小さいと考えて良い。今後のリプ レース延伸の観点からは，さらなる長期使用（想定以上： 30 年程度以上）を考えた場合の健全性評価が必要となる。 この場合，GIS における健全性評価の対象としては，固体 絶縁物内部（初期はボイドなし）が重要であると考えられ る。固体絶縁物内部（ボイドなし）では，インパルス電圧の 繰り返しによる V-N 特性の $\mathrm{n}$ 值が比較的小さく, 埋込電極 表面の微小突起や界面の剥離による微小ボイドが影響し微 小部分放電が発生して劣化が進行すると考えられている ${ }^{(8)}$ 。 このメカニズムから，想定以上の経年において，過電圧に よる部分放電の発生と微小ボイドの生成・進行および常規 電圧の長時間印加による部分放電の発生と劣化の進行が起 こるかを検討する必要がある。このため, 過電圧と常規電 圧の 2 種の電圧における V-t 特性および故障確率の評価が 重要であると考えられる。そこで，次章では電圧を複数回 印加した時の故障確率の考え方について考察する。

\section{3. 電圧を複数回印加したときの故障確率}

機器の試験法や寿命に関しては，機器に印加される種々 の電圧（常規電圧，試験電圧，過電圧）を考慮する必要が ある。このような電圧に対して機器の状態，とくに故障確 率がどうなるかは機器の特性（故障確率モデル）と印加状 況（電圧值，休止時間など）から考察しなければいけない。 これまで電力機器の試験法に関する検討では，電圧を複数 回印加したときの故障確率を常に初期状態（前歴や変化を 考慮しない) で考えていたが，これは厳密には正しくない。 以下では機器の故障確率がワイブル分布である場合につい て，複数回でも最も簡単な 2 回印加の場合を考える。

2 種類の電圧を印加したときの故障確率は，最初の印加 状態に対応して故障確率が変化する場合には，それによっ て確率密度関数が変化する, いわば複合型ワイブル分布と いうべき特性を考えなければいけないことが指摘されてお り，これに対するモデルが提案されている(1)(10)。本論文で は，既に報告されているこれらのモデルに加え，以下に 3 種類のモデルを検討する。

〈3・1〉 ワイブル分布簡単のため，ワイブル分布の 確率分布関数を (1) 式のように表す。

$$
P_{0}=1-\exp \left(-A V^{m} t^{a}\right), \quad A=V_{0}^{-m} T_{0}^{-a} \cdots \cdots \cdots
$$

このとき確率密度関数は，(2) 式となる。

$$
f_{0}=A a V^{m} t^{a-1} \exp \left(-A V^{m} t^{a}\right) .
$$

(1) 式から, 電圧 $V_{1}$, 時間 $0 \sim T_{1}$ の故障確率を $P_{1}$, 電圧 $V_{2}$, 時間 $0 \sim T_{2}$ の故障確率を $P_{2}$ とすると, これらは(3) 式で表 される。

$$
\left.\begin{array}{l}
P_{1}=1-\exp \left(-A V_{1}^{m} T_{1}^{a}\right) \\
P_{2}=1-\exp \left(-A V_{2}^{m} T_{2}^{a}\right)
\end{array}\right\}
$$

表 2 係数 $\alpha$ および $\beta$

Table 2. coefficient $\alpha$ and $\beta$.

\begin{tabular}{|c||c|c|}
\hline Model & $\alpha$ & $\beta$ \\
\hline \hline I $^{(1)}$ & $\exp \left[-A\left(V_{1}^{m}-V_{2}^{m}\right) T_{1}^{a}\right]$ & 0 \\
\hline II & $\exp \left(-A V_{1}^{m} T_{1}^{a}\right)$ & $T_{1}$ \\
\hline III $^{(10)}$ & 1 & $T_{1}\left[1-\left(V_{1} / V_{2}\right)^{m / a}\right]$ \\
\hline
\end{tabular}

以下では, 電圧 $V_{1}$, 時間 $0 \sim T_{1}$ 印加, 電圧 $V_{2}$, 時間 $T_{1} \sim$ $\left(T_{1}+T_{2}\right)$ 印加という場合を考える。

$\langle\mathbf{3} \cdot 2\rangle$ 確率密度関数の補正 2 種類の電圧を印加し たときの故障確率は, 最初の印加状態に対応して故障確率 が変化する特性を考える。ここでは, 以下の条件 (1)を設定 する。

（a）時間 $T_{1}$ 以降の故障確率が，電圧 $V_{1}$, 時間 $0 \sim T_{1}$ 印 加の故障確率と連続

(b) 無限大時間印加時の故障確率が 1 となる

(c) 機器の $\mathrm{V}-\mathrm{t}$ 特性の $\mathrm{n}$ 乗則を満たす

なお, 確率密度関数は $t=T_{1}$ において連続である必要はな い。むしろ異なる電圧が印加されるので, 不連続であるほ うが自然である。

この条件において, $t=T_{1}$ で $V_{2}$ が印加された場合の故 障率および確率密度関数は, 係数 $\alpha$ および $\beta$ を用いて以下 の形で表される。

$$
\begin{aligned}
& P=1-\alpha \exp \left[-A V_{2}^{m}(t-\beta)^{a}\right] \ldots \ldots \ldots \ldots \\
& f=\alpha A V_{2}^{m} a(t-\beta)^{a-1} \exp \left[-A V_{2}^{m}(t-\beta)^{a}\right]
\end{aligned}
$$

ここで, 係数 $\alpha$ および $\beta$ を表 2 に示す。文献 (1) および (10) での提案は，モデル I およびモデル III になる。モデル III での $V_{1}=0, V_{1}=V_{2}$ のケースは，それぞれモデル I, モ デル II に帰着する。

〈3·3〉 各モデルの特徵と問題点 モデル $\mathrm{I}$ は, $V_{1}, V_{2}$, $T_{1}$ が一定のとき, $V_{2}$ と $T_{1}$ 以後の $t$, あるいは $\left(T_{1}+T_{2}\right)$ との関係は $\mathrm{n}$ 乗則になっている。問題点としては, 時間 $T_{1}$ までは電圧が $V_{2}$ でなく $V_{1}$ であるにもかかわらず， $V_{2}$ と $\left(T_{1}+T_{2}\right)$ の関係が $\mathrm{n}$ 乗則になっている点などが挙げられる。 モデル II では， $V_{2}$ と $T_{2}$ の関係が $\mathrm{n}$ 乗則になっている。 問題点としては， $V_{2}=V_{1}$ という場合の故障確率が, もと のワイブル分布で $V_{1}$ を $\left(T_{1}+T_{2}\right)$ 印加したときの故障確 率の式と一致しない点などが挙げられる。モデル III は時 間をシフトさせて， $T_{2}$ からの $V_{2}$ の確率分布を $V_{1}$ の確率 分布に接続する方法である。このモデルでは， $V_{1}=0$ のと き，あるいは $V_{2}=V_{1}$ のとき，モデル I あるいはモデル II で生じた矛盾は生じない。

〈3・4〉 異なる電圧を印加したときの破壊特性図 1 に各モデルにおける確率分布の一例を示す。同図は，最初 に $V_{1}=2$ [a.u.] を印加し, $T_{1}=0.15$ [a.u.] で, $V_{2}=1$ [a.u.] を印加した場合であり, 各パラメータは, $m=4, a=2$, $A=1$ とした。また， $P_{1}$ のみおよび $P_{2}$ のみの場合も併記 
し， $P_{2}$ に関しては， $T_{1}=0.15$ を開始点としている。同図 は非常に極端な例であるが，例えば，最初に $V_{1}=2$ [a.u.] で比較的高い電圧が印加され，それによる履歴を考慮した $T_{1}=0.15$ [a.u.] 以降の確率分布は, $V_{2}=1$ [a.u.] の印加で 初期状態から考えた場合と比較して異なる。例えば，累積 確率 0.5 に到達する時間で見た場合， $P_{2}$ を初期状態から考 えると，時間は 1.0 程度であるが， $P_{1}$ の履歴を考慮すると， 各モデルで異なるが, $0.4 \sim 0.8$ 程度となる。このように, 例 えば常規電圧や過電圧を複合的に考えた場合では，規定の 故障確率に到達する時間が早くなる場合が想定される。

図 1 では，各モデルで確率分布が異なるが，〈3·3〉節で 示したとおり，モデル III は他と比べて合理的である。これ は基本的に異なる電圧印加において， $V^{m} t^{a}$ が同じであれば 同じ作用（故障あるいは一般的には状態変化）を及ぼすと いうことがベースになっている。しかし，最終的な判断は 対象とする機器の時間的変化の理論的考察や実験結果によ らなければいけない。これはそもそもワイブル分布という 故障確率そのものも， V-t 特性デー夕を満たす条件で導入さ れたもので，理論的に確立されたものでないことに注意す る必要がある。したがって，モデル I あるいはモデル II も， 故障確率（密度）として近似的に成立するかもしれない。

まず電圧印加が休止時間を伴って行われ, $V_{1}$ 印加後 $t=T_{1}$ において初期状態に戻ると考えて良いようなときは，最初 の $V_{1}$ の印加による故障確率の変化を考えず，初期状態か らの故障確率を与えるのが適当と思われる。

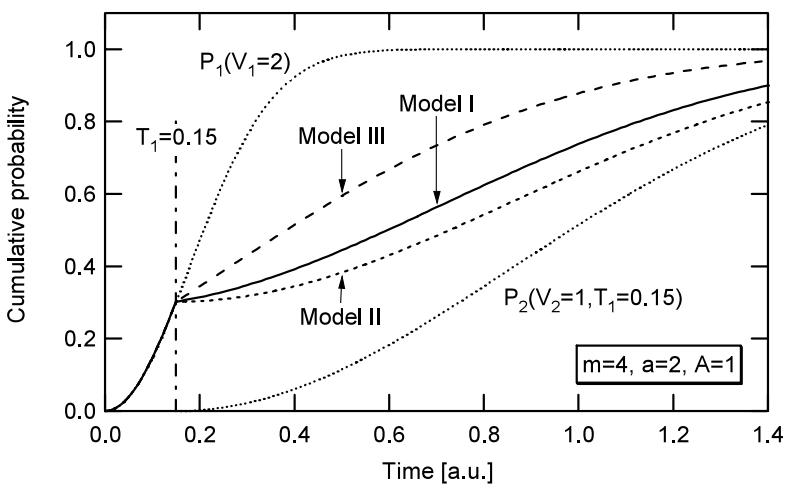

図 1 各モデルにおける確率分布の一例

Fig. 1. Example of cumulative probability for different models.
さらに，故障確率が変化した状態で次の電圧を印加する 場合も, 各モデルで電圧 $V_{2}$ に対する $\mathrm{n}$ 乗則が相違する。し たがってワイブル分布のメカニズム, あるいは電圧を 2 回 印加したときの V-t 特性 ( $\mathrm{n}$ 乗則), あるいは電圧の印加状 況に依存する。特に 2 回印加時の V-t 特性のデータが必要 である。

このような実験データは少なくとも GIS に係わる絶縁媒 体に関してはほとんどないようである。わずかに GIS 用の エポキシ樹脂スペーサについて, 交流課電, 雷インパルス, 開閉インパルス印加の影響（破壊電圧変化）が調ベられて いる ${ }^{(1)}$ 。その結果，たとえば交流課電による劣化によって $m$ 值が 15.4 から 10.6-10.8 の值に低下し, 雷インパルスで も同様に $m$ 值が低下するとされている。これまでの検討は このような $m$ 值の変化を考えていないので, 本論文で述べ ている経年機器への再度の絶縁試験における具体的な試験 法（試験電圧, 印加時間）の検討では, 新たな観点からの 考察が必要となる可能性がある。

\section{4. 絶縁試験によるリプレース期間延伸の可能性}

第 2 章では，絶縁媒体の長時間 V-t 特性のデータとその メカニズム, さらにはこれに基づく交流長時間試験法の決 定の経緯について整理した。本章では, 今後の高経年機器 に対して, 再度, 絶縁試験を実施することによる機器の健 全性評価およびリプレース時期延伸の可能性を検討した。

$\langle\mathbf{4} \cdot 1\rangle$ 絶縁特性と劣化要因 表 3 は, 長時間 V-t 特性 のデータなどから, 各機器の絶縁特性と主な劣化要因との 関係を整理したものである ${ }^{(6)}$ 。同表では，代表的な電力流 通設備である変圧器およびXLPE ケーブルについても比較 のため併記している。長時間 V-t 特性の $\mathrm{n}$ 值が小さいと電 圧印加による絶縁性能の低下が顕著であることから, $\mathrm{n}$ 值が 小さい GIS の絶縁スペーサと XLPE ケーブルについては, 主劣化要因は絶縁劣化と考えられている ${ }^{(6)}$ 。たたし, 通常 はこの劣化特性を考慮して電界ストレスを低く抑えるなど して長期の機器寿命を検討している。例えば，GIS では先 に述べたとおり，30 年後の絶縁物が耐え得る電界強度は, GIS の絶縁物に常時加わる電界強度の 2 倍以上に設定され ており，この期間での劣化は考慮しなくて良いと考えられ ている。いずれにせよ，スペーサ内部やXLPE ケーブルの

表 3 代表的な電力流通設備の絶縁特性と劣化要因との関係 ${ }^{(6)}$

Table 3. Relation between degradation factor and breakdown characteristics for typical power equipments.

\begin{tabular}{|c|c|c|c|c|c|}
\hline \multirow{2}{*}{ Equipment } & \multirow{2}{*}{$\begin{array}{l}\text { Insulation } \\
\text { medium }\end{array}$} & \multirow{2}{*}{$\begin{array}{c}\mathrm{n} \text { value } \\
\text { (Long term) }\end{array}$} & \multicolumn{2}{|c|}{ Deterioration factor } & \multirow{2}{*}{ Deterioration factor and spot } \\
\hline & & & Insulation & Others & \\
\hline GIS & $\begin{array}{c}\mathrm{SF}_{6} \\
+ \\
\text { epoxy resin } \\
\end{array}$ & $10-16$ & O & & $\begin{array}{l}\text { Partial discharge at interface of electrode in } \\
\text { spacer (There is little influence because working } \\
\text { stress is controlled (low).) }\end{array}$ \\
\hline Transformer & $\begin{array}{c}\text { Oil } \\
+ \\
\text { paper }\end{array}$ & $\begin{array}{c}60 \\
\text { (30 at short time) }\end{array}$ & & $\bigcirc$ & $\begin{array}{l}\text { Deterioration of insulation paper due to heat } \\
\text { (Consequently, intensity of tension declines for } \\
\text { short-circuit electromagnetic force.) }\end{array}$ \\
\hline XLPE cable & XLPE & $\begin{array}{c}15 \\
\text { (20 if it isn't flooded) }\end{array}$ & O & & Progress of water tree in XLPE \\
\hline
\end{tabular}


ように, 固体, 固体と電極の界面のような微小ギャップま たはボイドなど，欠陥が固定される絶縁構成では，その欠 陥での絶縁特性が支配的となり，ここから劣化が進行する 絶縁特性となる ${ }^{(6)}$ 。

一方, 変圧器では, $\mathrm{n}$ 值が比較的大きく, 絶縁紙の熱劣 化が主劣化要因と考えられており, 外部短絡時の電磁機械 力による絶縁紙の引張強度の低下が機器寿命を決定すると 考えられている。

$\langle\mathbf{4 \cdot 2}\rangle$ 劣化傾向と健全性評価図 2 に代表的な電力 流通設備の劣化傾向と保守コンセプトを示す。30 年程度の 経年を考えると，（1）設計電界等も考慮して劣化はほとん ど起こらない場合, (2) 絶縁設計では, 劣化特性を考慮し ているが, 現行の劣化検出手段で検出できる程度の何らか の劣化が進行する場合に大別できると考えられる。前者の 例は GIS, 後者の例は変圧器およびXLPE ケーブルである。 現行の設計寿命で固体絶縁物の絶縁劣化がほとんど起こ らないGIS では，偶発故障の事象が続き，絶縁に関しては バスタブ曲線はほぼフラットのままであることが想定され る。このため, 初期欠陥の検出で有効な部分放電測定など によって劣化状況を検出することは困難である。この場合 には，再度の絶縁試験で健全性を評価し，リプレース時期 の延伸（例えば $\mathrm{X}$ 年の長期信頼性保証）を図ることが可能 ではないかと考えられる。GIS の場合，スペーサの劣化は 電界 (絶縁) が主要因であると考えられることから，具体 的な試験法の検討においては，第 3 章で述べたような異な る電圧印加での絶縁特性 (V-t 特性) の検討が, 熱劣化など が複雑に影響する変圧器などよりも比較的容易であると考 えられる。

ここで, 固体絶縁物以外のコンポーネントに関しては, 劣 化，消耗状況に応じて，リフレッシュ（ガスの交換，開閉 接点の交換およびシール材などの劣化消耗品の交換）する ことが有効である。表 4 は GIS の各コンポーネントにおい て想定される劣化とメンテナンス方法をまとめたものであ る。固体絶縁スペーサを除く各コンポーネントは，Oーリン
グの経年劣化や, 開閉接点の消耗などが想定されるが, 夕 ンク開放を想定すれば，大部分は交換・修理が可能と考え られる。

一方, 変圧器や XLPE ケーブルのように, 劣化が進行す る機器については, 再度の絶縁試験前にそれまでの劣化状 況を把握し, さらに再度の絶縁試験によって想定される劣 化を考慮する必要がある。この場合, 絶縁試験によりそれ までの劣化をさらに進行させる可能性もある。このため, これらの機器については, 常時あるいは随時, 的確な劣化診 断により劣化状況を検出しつつ寿命限界まで使い切ること が有効であると考えられる。具体的には, 変圧器では, 平 均重合度による絶縁紙の熱劣化評価, 油中ガス分析による 評価が挙げられる。一方, XLPE ケーブルでは部分放電測 定などが挙げられる。

〈4・3〉 GIS における絶縁試験によるリプレース時期延 伸に向けた課題図 3 は高経年 GIS におけるリプレー ス時期延伸のフローを示したものである。新設機器導入時

表 4 GIS 各コンポーネントの劣化傾向と保守

Table 4. Supposed degradation and maintenance for GIS components.

\begin{tabular}{|c|c|c|}
\hline Component & Supposed degradation & Maintenance \\
\hline $\mathrm{SF}_{6}$ gas & $\begin{array}{l}\text { - Purity reduction } \\
\text { - Moisture mixing }\end{array}$ & $\begin{array}{l}\text { - Refilling of new } \\
\text { gas }\end{array}$ \\
\hline Solid Spacer & $\begin{array}{l}\text { - No degradation under } \\
\text { normal operating condition }\end{array}$ & - Not necessary \\
\hline Switching contact & $\begin{array}{l}\text { - Wear-out due to current } \\
\text { interruption }\end{array}$ & $\begin{array}{l}\text { - Exchange of } \\
\text { switching contact }\end{array}$ \\
\hline Connection of bus & $\begin{array}{l}\text { - No degradation unless } \\
\text { abnormal contact condition }\end{array}$ & - Not necessary \\
\hline $\begin{array}{l}\text { Mechanical moving } \\
\text { part } \\
\text { (including grease) }\end{array}$ & $\begin{array}{l}\text { - Hardening in moving } \\
\text { operation } \\
\text { - Mechanical damage }\end{array}$ & - Repairable \\
\hline Adsorbent & $\begin{array}{l}\text { - Reduction in adsorpution } \\
\text { by chemical degradation }\end{array}$ & - Replaceable \\
\hline $\begin{array}{l}\text { Gasket } \\
\text { (O-ring, etc.) }\end{array}$ & $\begin{array}{l}\text { - Hardening with time and } \\
\text { heat cycle }\end{array}$ & $\begin{array}{l}\text { - Replaceable } \\
\text { ( Irreplaceable in } \\
\text { some part in GIS) }\end{array}$ \\
\hline Tank, flange & - Surface rust and corrosion & - Repairable \\
\hline
\end{tabular}

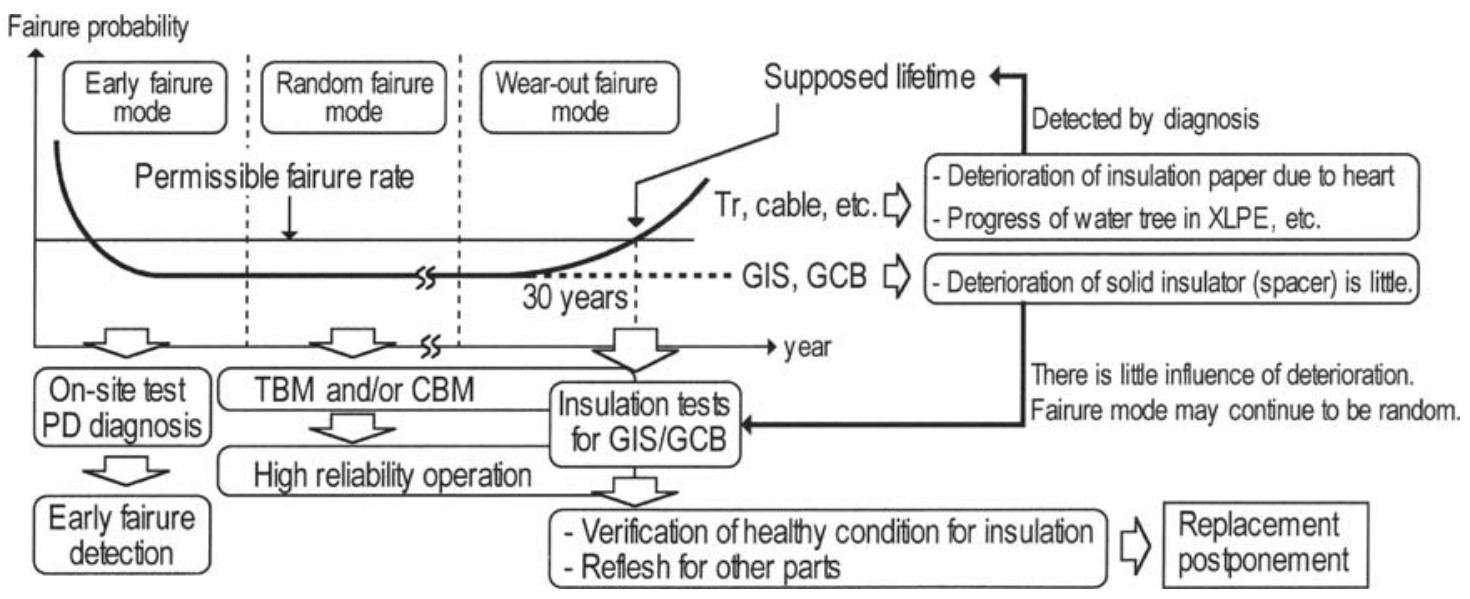

図 2 代表的な電力流通設備の劣化傾向と保守コンセプト

Fig. 2. Deterioration tendency and maintenance concept for typical power equipments. 


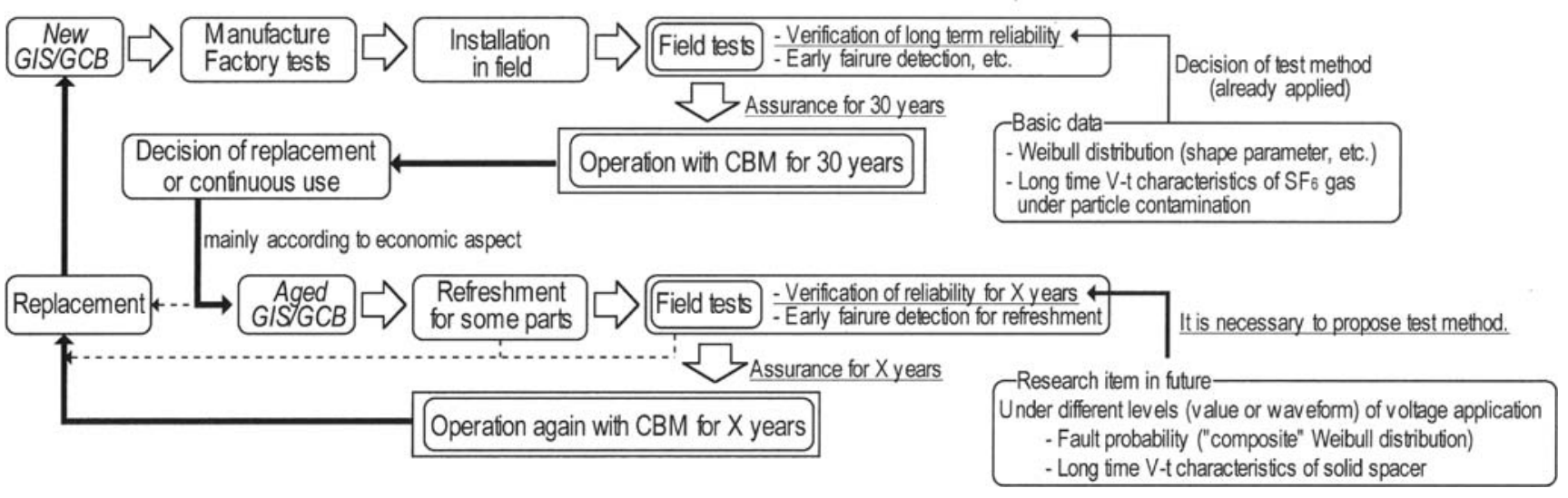

図 3 高経年 GIS におけるリプレース時期延伸のフロー

Fig. 3. Flowchart of replacement postponement for aged GIS.

の長期信頼性試験において保証された想定寿命（例えば 30

年）到達時点で，機器をリプレースするか，さらに継続使 用するかを決定する。ここでは，主に経済的局面によって 決定されることが予想される。継続使用が決定した場合で も，先に述べたとおり，Oーリング等交換が必要な部品も想 定されるため，タンクを開放し当該部品のリフレッシュを 図る。その後, リフレッシュによる初期欠陷の検出および 長期信頼性保証（例えば X 年）のための絶縁試験を実施し, クリアすれば再度運用に入る。この間，何らかの不具合に よりリプレース延伸が不可となる場合も想定されるが，こ れまでの運転実績, 高信頼性, 劣化状況調査などから，そ のようなケースはごくまれであると考えられる。

高経年の固体絶縁スペーサの長期信頼性保証に関しては, 第 3 章で述べたようなより厳密な故障確率および V-t 特性 の評価からの検討が GIS の高信頼性維持の観点から重要で ある。図 4 に GIS の高経年使用時における固体絶縁スペー サの健全性評価に関する研究課題を示す。スペーサの劣化 メカニズムを考えると，第 2 章で述べたとおり，固体絶縁 物内部（ボイドなし）における埋込電極表面の微小突起や 界面の剥離による微小ボイドが影響し, 微小部分放電が発 生して劣化が進行することが考えられる。このメカニズム から, 機器の運転状態では, 過電圧による部分放電の発生 と微小ボイドの生成・進行および常規電圧の長時間印加に よる部分放電の発生と劣化の進行が考えられる。このため, 過電圧と常規電圧の 2 種の電圧における寿命評価が重要で あると考えられる。さらに, 過電圧による微小ボイドから の部分放電の発生を健全性評価の観点から非常に高感度の 部分放電検出レベルで実施できれば，スペーサの健全性評 価（スペーサのリユース）にも繋がると考えられる。

従来の実機器で想定される範囲（想定寿命内）で，この ような 2 種の電圧におけるデータが取得されており ${ }^{(11)}$, 顕 著な劣化は見られないとの報告があるが, 更なる長期使用 も想定したデー夕取得が重要と考えられる。すなわち, 過 電圧の繰り返しによる劣化を考慮した長時間 V-t 特性と統 計的パラメータ值（n, m, a 值）の基礎データの取得が必

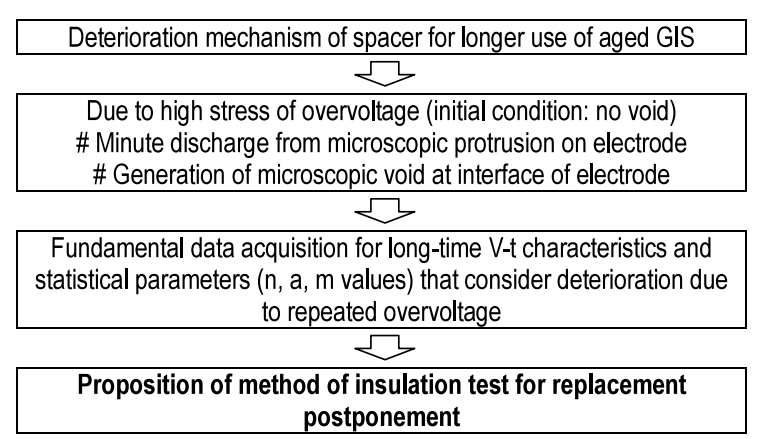

図 4 GIS の高経年使用時における固体絶縁ス ペーサの健全性評価に関する研究課題

Fig. 4. Research items for estimation of healthy condition of solid insulation spacer for aged GIS.

要である。さらに, $\mathrm{m}$ 值などの統計的パラメータが変化す るなどの結果 ${ }^{(11)}$ が報告されており, 実機器のスペーサを含 む高経年の固体絶縁スペーサにおける統計パラメータおよ び V-t 特性を再評価した上で，リプレース時期延伸のため の具体的な絶縁試験法を提案する必要がある。本論文では, 高経年 GIS への絶縁再試験によるリプレース時期延伸の可 能性を示し, 適切な絶縁試験法を提案するための問題提起 を行った。今後は, 本論文で述べた実験データの取得およ びそれに基づく具体的な試験法について検討を進める。

\section{5. まとめ}

GIS を中心としたガス絶縁機器を対象に, 現行の長時間 $\mathrm{V}-\mathrm{t}$ 特性および絶縁試験の考え方を整理し, 経年機器におけ る再度の絶縁試験によるリプレース時期延伸の可能性につ いて検討した。

現行の設計寿命でほとんど劣化しない (非劣化型) と考 えられる GIS では, 機器をリフレッシュなどした後, 再度 の絶縁試験で健全性を再評価することが可能と考えられる。 一方で, 変圧器およびXLPE ケーブル等の劣化累積型機器 では, 絶縁設計において劣化特性を考慮し, 現行の劣化検 出手段で劣化を検出できると考えられる。この場合, 常時 
あるいは随時これらの劣化診断により劣化状況を検出する ことが寿命評価に有効であると考えられる。

さらに，印加時間や值の異なる電圧が印加された場合の 故障確率の考え方を整理した。GIS のような非劣化型の機 器を対象とした再度の絶縁試験による健全性評価では，複 合ストレスによる V-t 特性データおよび故障確率の評価が 必要であることを示した。すなわち, 過電圧の繰り返しに よる劣化を考慮した長時間 V-t 特性と統計的パラメー夕值 の基礎データから， V-t 特性を再評価した上で，リプレー ス時期延伸のための具体的な絶縁試験法を提案する必要が ある。

最後に，本研究の実施にあたりご協力頂いた（財）電力 中央研究所電力技術研究所高橋紹大主任研究員, 水谷嘉伸 主任研究員, 高橋俊裕主任研究員, 栗原隆史研究員に厚く 御礼申し上げます。

(平成 17 年 9 月 26 日受付，平成 18 年 2 月 2 日再受付)

\section{文献}

(1) T. Takuma: "Consideration on AC (Power-Frequency) Insulation Tests for High Voltage Power Equipment", IEEJ Trans. PE, Vol.124, No.7, pp.977_ 983 (2004-7) (in Japanese)

宅間 董:「電力機器の交流絶縁試験に対する考察」, 電学論 B, 124, 7,pp.977-983 (2004-7)

（2）電気協同研究会絶縁設計合理化専門委員会：「絶縁設計の合理化」,電 気協同研究, Vol.44, No.3 (1988)

（3）岡庭 潔 - 財満英一 - 青柳浩邦 - 小山 博 - 大久保仁 ·上原京一 : $\lceil\mathrm{GIS}$ 実器モデル (66 kV 母線) の長時間 V-t 特性」, 昭和 63 年電気 学会全国大会, No.1173, p.1534 (1988)

（4）青柳浩邦·本多正己·小林伸光：「各種絶縁材料の V-t（破壊電圧一 時間）特性——基礎から実用面まで——エポキシ絶縁物」,昭和 56 年電気四学会連合大会シンポジウム, S13-4, pp.2-119-2-122 (1981)

（5）青柳浩邦・小屋政吉・岡本幸男：「エポキシ注形品の長時間寿命特 性」,昭和 49 年電気学会全国大会, No.331,p.421 (1974)

(6) 電気学会電力システムにおける機器共通の高電圧絶縁技術調査専門 委員会：「電力機器 - 絶縁材料技術の横断的評価と共通技術の体系 化」, 電気学会技術報告, No.945 (2003)

( 7 ) M. Honda, H. Aoyagi, M. Koya, N. Kobayashi, and M. Tamura: "V-t Characteristics of Epoxy Mold Insulation for Sustained AC Voltage", IEEE Trans. Power Apparatus Syst., Vol.PAS-103, No.5, pp.1017-1023 (1984)

(8) S. Okabe, T. Ono, E. Zaima, H. Aoyagi, H. Murase, and I. Oshima: "Deterioration Characteristics of Insulating Spacer Model toward Repeating Impulse Voltage", T. IEE Japan, Vol.115-B, No.8, pp.978-984 (1995-8) (in Japanese)

岡部成光 $\cdot$ 大野高広 $\cdot$ 財満英一 ·青柳浩邦 $\cdot$ 村瀬 洋，大島 峳 「GIS スペーサ内部モデルの繰り返しインパルス絶縁特性」, 電学論 B, 115, 8, pp.978-984 (1995-8)

(9) S. Okabe, T. Ono, E. Zaima, K. Kobayashi, T. Yamagiwa, and F. Endo: "Surface Insulation Characteristics of a GIS Spacer Model for Repeated Impulse Voltage", T. IEE Japan, Vol.115-B, No.2, pp.187-193 (1995-2) (in Japanese)

岡部成光 - 大野高広 - 財満英一 - 小林健三 - 山極時生 - 遠藤奎将 : 「GIS 用スペーサ沿面モデルの繰り返しインパルス絶縁特性」, 電学 論 B, 115, 2, pp.187-193 (1995-2)
(10) H. Hirose: "Theoretical Foundation for Residual Lifetime Estimation", T. IEE Japan, Vol.116-B, No.2, pp.168-173 (1996-2)

11) S. Okabe, E. Zaima, K. Inami, K. Sasamori, and S. Sakuma: "Deterioration Characteristics of Model of Insulating Spacer for GIS under AC and Impulse Voltage", T. IEE Japan, Vol.115-B, No.1, pp.30-35 (1995-1) (in Japanese) 岡部成光・財満英一・井波 潔・笹森健次・佐久間秀一：「GIS 用又 ペーサ内部モデルの交流, インパルス電圧絶縁劣化特性」, 電学論 $\mathrm{B}$, 115, 1, pp.30-35 (1995-1)

五島久司 (正員) 1969 年 9 月 12 日生。1996 年 3 月名古

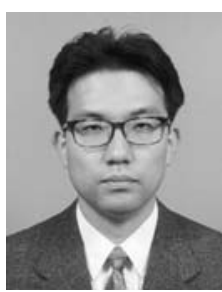
屋大学大学院工学研究科電気工学専攻博士課程後 期課程修了。同年 4 月 (財) 電力中央研究所入所, 現在に至る。主としてガス絶縁機器の絶縁技術, 雷放電に伴う電磁界現象に関する研究に従事。博 士 (工学)。1996 年および 2005 年電気学会論文 賞受賞。

八島 政 史 (正員) 1959 年 1 月 24 日生。 1983 年 3 月九州大

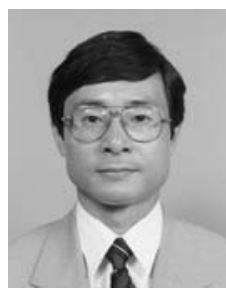
学大学院総合理工学研究科エネルギー変換工学専 攻修士課程修了。同年 4 月 (財) 電力中央研究所入 所，現在に至る。主としてガス絶縁機器の絶縁技 術に関する研究に従事。博士 (工学)。1992 年〜 1993 年カナダ・マニトバ大学客員研究員。1989 年，1994 年および 2005 年電気学会論文賞受賞。 IEEE 会員。

新 藤 孝 敏 (正員) 1953 年 11 月 21 日生。1978 年 3 月東

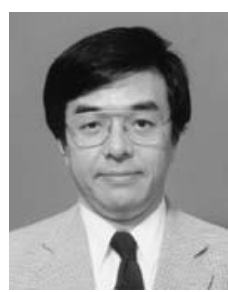
京大学大学院工学研究科修士課程修了。同年 4 月 (財) 電力中央研究所入所, 現在に至る。主として 大気中の放電現象, 送変電設備の外部絶縁設計に関 する研究に従事。工学博士。1987 年〜1988 年ア メリカ・フロリダ大学客員研究員。IEEE Fellow。 日本大気電気学会会員。

宅 間 董 (正員) 1938 年 9 月 30 日生。1966 年東京大学

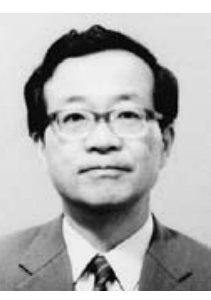
大学院博士課程修了。工学博士。同年同大学電気 工学科講師。1967 年 (財) 電力中央研究所入所。 高電圧, 放電, 電磁界解析, 核融合などの研究に 従事。1989 年 1993 年九州大学客員教授。1995 年 2002 年京都大学大学院工学研究科教授。2002 年から電力中央研究所研究顧問。2004 年東京電機 大学教授。1975 年英国電気学会 Maxwell 賞, 1981 年および 1991 年電気学会著作賞, 1992 年業績賞ならびに科学技術庁 長官賞受賞。IEEE Fellow。 